\title{
Implementation of Investigator's Authority for Confiscating the Notary Original Deed in Bukittinggi Police Station
}

\author{
Elfi Rahmi Hasnul; Elwi Danil; Yoserwan \\ Faculty of Law, Universitas Andalas Padang, Indonesia \\ http://dx.doi.org/10.18415/ijmmu.v6i2.682
}

\begin{abstract}
In carrying out the duties, the notary applies as an official who makes authentic deeds in the form of original deed. Original deed is a state document made by a notary as a public official which is then placed in storage in the notary's office. In this case, it is also a confidential profession of a notary. The problems are: 1) how the implementation of confiscation of notary original deed by investigator in Bukitinggi Police Station, 2) what are the obstacles in carrying out the confiscation of the notary original deed by investigator in Bukitinggi Police Station, and 3) what efforts to overcome the obstacles experienced by investigator in carrying out the confiscation of the notary original deed in Bukittinggi Police Station. This research applies an empirical juridical method. The characteristic of this research is descriptive analysis. All research data will be analyzed qualitatively. The research findings include: 1) the implementation of confiscation of notary original deed by investigator in Bukitinggi Police Station can be performed by requesting prior approval from the Regional Honorary Board of Notaries, 2) the obstacles in the confiscation of notary original deed by investigator in Bukitinggi Police Station is the time period, 3) effort to overcome the obstacles experienced by investigator in confiscating the notary original deed in Bukittinggi Police Station is to provide explanation and understanding.
\end{abstract}

Keywords: Implementation; Authority; Confiscation; Notary Original Deed; Investigator

\section{Introduction}

Legal needs in the community can be seen from the increasing number of agreements that are included in a notary deed. In this case, notary is one of the public officials who has the authority to make authentic deeds and other authorities as stated in the Law (Hendra, 2012). The authority to make this authentic deed is only carried out by the notary as long as the making of certain authentic deeds is not specifically for other public officials (Dinaryanti, 2013). Therefore, it is concluded that the notary is the only public official who has the authority to do so.

Authentic deeds provide a perfect proof between the parties and their heirs and have binding powers (Santoso, 2009). Perfect means that an authentic deed is sufficient to prove an event or circumstance without requiring the addition of other evidence. Binding means that everything listed on the deed must be trusted and considered to have actually happened. Thus, if there are parties who deny or 
doubt the truth, then that party must prove the doubts and untruths of the authentic deed (Arisaputra, 2012). One other requirement that must be added in the authentic deed is that the contents therein include all the elements of written evidence, witnesses, assumptions, confessions, and oaths.

In carrying out duties as authentic deed-making officials, notaries make authentic deed in the form of original deed (Suwignyo, 2009). The obligation to make a deed in the form of original deed is stated in Article 16 paragraph (1) number 2 of the Law of Notary Profession; i.e. making deed in original form and storing it as part of the notary protocol. The original definition of deed is formulated in Article 1 number 8 of the Law of Notary Profession; i.e. the original deed which includes the signatures of the viewers, witnesses and the notary him//herself which is then stored as part of the notary protocol.

In carrying out his/her office duties, a notary is a person who is trusted by the client and is obliged to keep everything the client tells him/her. This is the basis of the conduct of the confidential profession that has been given by the community - especially the clients - to him/her. This confidential information must still be maintained even though the relationship between the notary and the client in a professional manner has ended.

Keeping information about the deed that has been made by a notary is a form of notary protection against parties related to the deed. It includes when a notary is asked to give his/her testimony about the deed at the trial in a court. If a notary is called to be a witness at the trial in a court, he/she can use the confidentiality obligation of his/her profession in accordance with Article 16 paragraph (1) number 6 of the Law of Notary Profession which states that in carrying out his/her position, the notary must keep everything confidential about the deed he/she made and all information that he/she obtained to make the deed in accordance with the oath/ promise of profession; unless the law determines otherwise.

\section{Literature Review}

\section{Notary as General Officer}

The provisions of Article 1 number 1 of the Law of the Republic of Indonesia number 2 of 2014 concerning amendments to Law number 30 of 2004 concerning Notary Profession provide the understanding that a notary is a public official who has the authority to make authentic deeds and other authorities as stated in this Law or based on other laws. The use of the word 'authority in Article 1 above is needed because it relates to the provisions in Article 1868 of the Civil Code which states that "an authentic deed is a deed whose form is determined by law and made by or before public officials in power for this matter at the place of deed is made". In the implementation of Article 1868 of the Civil Code, the legislators must make legislation to appoint authorized or powerful public officials to make authentic deeds. Therefore, notaries are appointed as officials according to the provisions of Article 1 of the Law of Notary Profession.

The notary authority to make authentic deeds, which is regulated in the provisions of Article 1 paragraph 1 of the Law of Notary Profession, is further explained in the provisions of Article 15 paragraph 1 of the Law of Notary Profession. As a general officer, based on the provisions of Article 2 of the Law of Notary Profession, a notary is appointed and dismissed by the Minister; in this case, the Minister of Law and Human Rights of the Republic of Indonesia. In addition, they previously had to fulfill the requirements to be appointed as a notary, among others: Indonesian citizen, fearing the Almighty God, aged 27 (twenty-seven) years old, physically and mentally healthy, having a legal degree and graduated from master's degree of notary, has undergone internships or has obviously worked as notary employees within 12 (twelve) months in a row at the notary's office on their own initiative or on the recommendation of a notary organization after graduating from master's degree of notary and not 
having the status of a civil servant, an advocate state official or not holding another position which is prohibited by the Law to be concurrent with the Notary Profession.

\section{Authority, Obligations, and Prohibitions in Notary Profession}

The main authority of a notary is to make authentic deeds. The authenticity of the notary deed comes from the fact that the notary is a public official as stipulated in Article 1 of Law number 2 of 2014 concerning amendments to Law number 30 of 2004 concerning Notary Profession. Thus, the deed made by a notary in his/her profession is an authentic deed. In other words, the deed made by a notary is authentic. It is not only due to the stipulation contained in the Law, but also because of the deed is made by or before a public official, as referred to in Article 1868 of the Civil Code.

Notary authority has been determined by Article 15 of the Law of Notary Profession. Article 15 paragraph (1) of the Law of Notary Profession states that:

The notary is authorized to make authentic deeds regarding all acts, agreements, and stipulations that are required by legislation and/or desired by interested parties so that they are stated in authentic deeds, guarantee the date of deed, keep the deed, give the grosse, copy and duplicate of the deed; all of them as long as the making of the deed are not also assigned or excluded to other officials or other people as determined by the Law.

In carrying out the profession, the notary is obliged to:

a. act trustworthy, honest, thorough, independent, neutral, and safeguard the interests of the parties involved in legal actions;

b. make the deed in the form of original deed and save it as part of the notary protocol;

c. attach letters, documents and fingerprints of the viewers to the original deed;

d. issue grosse, copy and/or quotation of the deeds based on the original deed;

e. provide services in accordance with the provisions in the Law, unless there is a reason to reject them;

f. keep everything about the deed that he/she made confidential and all the information he/she obtained in the process of making the deed in accordance with the oath/promise of the profession, unless the Law stipulates otherwise;

g. bind the deed made in 1 (one) month into a book containing no more than 50 (fifty) deeds (if the number of deeds cannot be bound in one book, the deed can be bound to more than one book) and record the number of original deeds including the month and year of issuing on the cover of each book;

h. make a list of protest documents against no-payment or no-receipt of securities;

i. make a list of deeds relating to the will according to the order in which the deed is made each month;

j. send a list of deeds as referred to in letter i or a nil list with regard to a will to the center of the will list in the ministry that administers government affairs in the legal field within 5 (five) days in the first week of each subsequent month;

k. record the date of delivery of the will list at the end of each month in the repertoire;

1. have a sign or stamp that contains the state emblem of the Republic of Indonesia which in the space that surrounds it is written the name, profession, and place of residence of the concerned notary;

m. read the deed in the presence of the viewers which is attended by at least 2 (two) witnesses, or 4 (four) special witnesses for the making of private deed of wills and signed at that time by the viewers, witnesses and notary; and

n. accept prospective notary interns. 
The obligation to save the original deed as referred to in paragraph (1) letter b does not apply, in the event that the notary issues the in-original deed.

a. The in-original deed as referred to in paragraph (2) includes:

b. Deed of payment for rent, interest and pension;

c. Deed of cash payment offer;

d. Deed of protest against no-payment or no-receipt of securities;

e. Deed of attorney;

f. Deed of certificate of ownership; and

g. Other deeds in accordance with statutory provisions.

h. The in-original deed as referred to in paragraph (2) can be made more than 1 (one) copy, signed at the same time, form and content, provided that on each deed written the words "APPLY AS ONE AND ONE APPLY TO ALL".

i. The in-original deed containing attorney that has not been filled in with the name of the recipient of the attorney can only be made in 1 (one) copy.

j. The shape and size of the sign or stamp as referred to in paragraph (1) letter i shall be stipulated by a Ministerial Regulation.

$\mathrm{k}$. The reading of the deed as referred to in paragraph (1) letter $\mathrm{m}$ is not obligatory if the viewers want the deed not to be read because the viewers have read it themselves, know, and understand its contents; provided that it is stated in the cover of the deed and each page of in-original deed is initialed by the viewers, witnesses and notaries.

1. Provisions as referred to in paragraph (7) are excluded from the reading of the head of the deed, comparison, explanation of the main content of the deed briefly and clearly, and closing of the deed.

m. If one of the conditions referred to in paragraph (1) letter $\mathrm{m}$ and paragraph (7) is not fulfilled, the deed concerned only has proof power as a private deed.

n. Provisions as referred to in paragraph (9) do not apply to the making of a will.

The Law of Notary Profession also regulates the Prohibitions in Notary Profession. This is intended to guarantee the interests of the people who need notary services in making deeds. Article 17 of the Law of Notary Profession concerning the Prohibitions in Notary Profession, states that notaries are prohibited from:

a. Carry out the profession outside the scope of his/her profession. The prohibition in this provision is intended to provide legal certainty to the public and at the same time prevent unfair competition between notaries in carrying out their profession.

b. Leave the profession area more than 7 (seven) consecutive working days without valid reasons.

c. Have a double profession as a civil servant.

d. Have a double profession as a state official.

e. Have a double profession as an advocate.

f. Have a double profession as a leader or employee of a State-Owned Enterprise, RegionalOwned, or Private Enterprise.

g. Have a double profession as an official making land deeds outside the professional area of the notary concerned.

h. Become a substitute notary. Prohibition to become a substitute notary applies to a notary who has not carried out his/her profession, a notary who is undergoing a period of leave, and a notary who is in the process of moving the profession area.

i. Do other work that is contrary to religious norms, decency, or propriety that can affect the honor and dignity of the notary profession. 


\section{Authentic Deed}

The definition of authentic deed is stated in the provisions of Article 1868 of the Civil Code. It mentions that authentic deed is a deed whose form is determined by the Law, which is made by or before general employees who are in charge of this matter where the deed is made.

Furthermore, Prof. Dr. Sudikno Mertokusumo SH argues that authentic deed is deed made by officials authorized by the authorities according to stipulated provisions, with or without assistance from interested parties, who record what is requested to be included in it by those concerned. Authentic deed mainly contains information from an official who explains what happened and is seen before him/her.

Based on Article 1868 of the Civil Code, authentic deed must meet the following requirements:

a. The deed must be made "by" (door) or "before" (tenoverstaan) a public official.

b. The deed must be made in the form specified by the Law.

c. General officials or anyone who witnesses the deed is made must have the authority to make the deed.

\section{Investigator}

Investigator, according to Article 1 point 1 of the Criminal Procedure Code, are state police officers of the Republic of Indonesia or certain civil servant officials who are given special authority by the Law to conduct investigation. Furthermore, the Criminal Procedure Code regulates investigators in Article 6 which limits the investigating officials in criminal proceedings. Limitations of officials at the stage of the investigation included police investigation officer of the Republic of Indonesia and civilian investigative officials.

\section{a. Police Investigation Officer of the Republic of Indonesia}

According to the explanation of Article 6 paragraph (2), the position and ranks stipulated in the Government Regulation are harmonized and balanced with the position and rank of the public prosecutor and public justice judge. The Government Regulation which regulates the issue of investigator rank is in the form of Government Regulation number 27 of 1983.

\section{b. Civil Servant Investigator}

Civil Servant Investigator is regulated in Article 6 paragraph (1) letter b Criminal Procedure Code; i.e. civil servants who have the function and authority as investigators. Basically, the authority they have comes from a special criminal law, which has stipulated its own authority to investigate one of the articles. The investigative authority possessed by civil servant officials is only limited to matters relating to criminal acts stipulated in the specific criminal law. This is in accordance with the limitation of authority mentioned in Article 7 paragraph (2) of the Criminal Procedure Code which states that: "civil servant investigators as referred to in Article 6 paragraph (1) letter b have the authority in accordance with the Law which becomes their legal basis and the implementation of their duties is under the coordination and supervision of the Police Investigation Officer of the Republic of Indonesia".

\section{Investigation}

Investigation is the stage of criminal case settlement after an investigation which is the initial stage in seeking the presence or absence of a crime in an event. 
The definition of investigation is contained in Article 1 point 2 of the Criminal Procedure Code Chapter I concerning General Explanation explains that: "investigation is a series of investigative actions in terms of and according to the method stipulated in the Law to find and collect evidence that the evidence makes clear about the crime that occurred and to find the suspect".

\section{Confiscation}

Based on Article 1 point 16 of the Criminal Procedure Code, confiscation is a series of actions by investigators to take over and/ or save under the control of movable or immovable, tangible or intangible objects for the purposes of evidence in investigation, prosecution and examination in court.

\section{Research Analysis}

1. Implementation of Confiscating the Notary Original Deed by Investigator in Bukittinggi Police Station

The procedures for carrying out the confiscation of ordinary or general forms are:

a. Have a confiscation permit from the head of the court.

b. Showing and providing identification.

c. Showing objects to be confiscated.

d. The seizure process must be witnessed by the village head or ward chairman with two witnesses.

e. Make a confiscation report.

f. Submitting a copy of the confiscation report.

g. Wrapping confiscated object.

\section{Conditions for Implementing the Confiscation of Original Deed Notary}

The conditions for confiscating the copy of original deed are stipulated in Article 3 of the Regulation of the Minister of Law and Human Rights number M.03.HT.03.10 in 2007 as follows:

a. there is an alleged criminal offense relating to the original deed and/or letters attached to the original deed or notary protocol in the storage of a notary, or

b. the right to sue based on the provisions regarding the expiration of the laws and regulations in the criminal field has not yet completed.

Based on the results of interview with Mr. Eka Kurniawan SH, an investigator of the crime and recession unit in the Bukittinggi Police Station, the conditions for carrying out the confiscation of original deed notary include:

a. The investigator must make a written letter in the form of a letter submitting an application for approval of the original deed or notary protocol confiscation to the Chair of the Regional Honorary Board of Notaries in accordance with the working area of the notary concerned.

b. The investigator must attach proof of the report from the reporter regarding the case and also attach the chronology of the case.

c. The investigator sent the letter to the Regional Honorary Board of Notaries. 


\section{Processes and Procedures for Implementing the Confiscation of Notary Original Deed}

The examination/investigation procedure is the administrative stage that must be taken to carry out an inspection activity in a series of police actions. Thus, the implementation of the inspection fulfills juridical and administrative requirements.

Basically, investigation procedures include:

a. General procedures based on the Criminal Procedure Code;

b. Special procedures based on the Law governing it.

In this case, the implementation procedures are as follows:

a. The police investigator submits a letter of application for approval of confiscating the original deed or notary protocol to the Chair of the Regional Honorary Board of Notaries in accordance with the working area of the notary concerned. ${ }^{1}$

b. The investigator mentioned the need related to the letter, whether it is to take the copy of original deed and/or letters attached to the original deed or notary protocol in notary storage or the need to call a notary to attend the examination relating to the original deed he/she made or notary protocol which is in the notary storage.

In the application letter, the case and the suspect are briefly explained. above.

After obtaining approval, the investigator can take action by the Police as stated in number 1

The processes and procedures for carrying out the confiscation of notary original deed include:

a. There are report and the process of making a report.

b. The investigator makes a written letter to the Regional Honorary Board of Notaries.

c. The investigator awaits confirmation from the Regional Honorary Board of Notaries.

d. There was confirmation from the Regional Honorary Board of Notaries.

Based on the results of interview with the Notary Husna Misbah SH, the original deed related confiscation is basically nonexistent. However, investigator only asks the copy of the original deed. According to the Minister of Law and Human Rights Regulation number M.03.HT.03.10 of 2007, the copy of the original deed can be asked by requesting prior approval from the Regional Honorary Board of Notaries. In this case, the investigator makes a letter to the Regional Honorary Board of Notaries to request the copy of the original deed.

As requested by the investigator, the notary can be summoned to the Regional Honorary Board of Notaries in Padang City. From the results of the discussion, the Regional Honorary Board of Notaries will determine whether or not to provide a dispute or refusal to carry out confiscation.

It turns out that in the natural case of a notary, the Regional Honorary Board of Notaries gives approval to the investigator to confiscate the copy of the original deed and the Honorary Board of Notaries issued a letter in the form of approval to the investigator. So, based on a letter of approval from the Regional Honorary Board of Notaries, the investigator comes to the notary's office to request the copy of the original deed.

After the investigator asks the copy of the original deed and the notary sees the letter from the Regional Honorary Board of Notaries, the notary copies the original deed and makes the original deed submission report. The notary submits the report to the investigator with a witness of 2 (two) people; 1 (one) from the police and 1 (one) from the notary employee. 
Based on the results of an interview with Notary Elfita Achtar SH, what actually happened is not the confiscation of the notary original deed, but the confiscation of a certificate in which the notary does not want to give a certificate to the investigator because the investigator does not want to give the report. If the certificate is given to the investigator, the notary can be blamed for giving it to the unauthorized person. Therefore, the next investigator's effort was a forced effort in the form of a search. Search must be conducted with the determination of the Chair of the local District Court.

\section{Constraints in Confiscation the Notary Original Deed by Investigator in Bukitinggi Police Station}

Based on the results of interview with Mr. Eka Kurniawan SH, an investigator of the crime and recession unit in the Bukittinggi Police Station, the constraints in confiscating the notary original deed by the investigator is related to the period of time. The period of authority of the Honorary Board of Notaries to provide approval for confiscation of original deed has a maximum of 1 (one) month in the form of approval or rejection of the application.

The period of the investigation process carried out by investigators for cases relating to falsification of signatures or forgery of letters is classified as a moderate case. This moderate case means that investigator has approximately 1 (one) month to conduct an investigation. In other words, within 1 (one) month, it is clear whether this case is criminal or not.

Article 23 paragraph (4) and (5) of the Minister of Law and Human Rights Regulation number 7 of 2016 states that the Chair of the Honorary Board of Notaries is obliged to provide an answer in the form of approval or rejection of the application within a maximum of 30 working days from the date of receipt of the application. If the period is exceeded, the Regional Honorary Board of Notaries is deemed to receive a request for approval.

\section{Efforts to Overcome Constraints Encountered by Investigators in Conducting Confiscation of Notary Original Deed in Bukittinggi Police Station}

Based on the results of interview with Mr. Eka Kurniawan SH, an investigator of the crime and recession unit in the Bukittinggi Police Station, attempts to overcome the constraints encountered by investigators in carrying out confiscation of the original deed are: the investigator explains to the reporter regarding the progress of the case and tell the reporter that the investigating team has submitted a request letter of confiscation to the Regional Honorary Board of Notaries.

Within a period of 1 (one) month, the investigator must wait whether the submitted application letter has been approved or rejected to carry out the confiscation. The reporter will keep asking the investigator about how the case is going, so that the investigator needs provide understanding to the reporter that this is in accordance with the rules.

If 1 (one) month passes and there is no notification, the investigator considers that the Regional Honorary Board of Notaries has accepted or approved the request for approval and the investigator will then immediately confiscate the copy of the notary original deed.

\section{Closing}

\section{Conclusions}

The implementation of confiscation of the notary original deed by an investigator in the Bukittinggi Police Station can be carried out if it only needs the copy of the original deed. According to 
the Minister of Law and Human Rights Regulation number M.03.HT.03.10 in 2007, the copy of the original deed can be asked by requesting prior approval from the Regional Honorary Board of Notaries. If it is related to a civil case, the Regional Honorary Board of Notaries will not give approval, but if it is a criminal case, the Regional Honorary Board of Notaries will certainly give approval for the interests of judicial proceedings, investigators, public prosecutors or judges. The process and requirements for confiscation carried out by investigators are clearly stipulated in the Criminal Procedure Code.

The constraints in confiscating the notary original deed by the investigator in Bukittinggi Police Station is related to the period of time. The period of the Honorary Board of Notaries to provide approval or rejection for confiscation of the original deed has a maximum of 1 (one) month.

The period of the investigation process carried out by investigators for cases relating to falsification of signatures or forgery of letters is classified as a moderate case. This moderate case means that investigator has approximately 1 (one) month to conduct an investigation. In other words, within 1 (one) month, it is clear whether this case is criminal or not.

The effort to overcome the constraints encountered by investigator in carrying out the confiscation of the notary original deed in Bukittinggi Police Station is to explain to the reporter regarding the progress of the case and convey to the reporter that the investigating team has given a letter requesting a confiscation to the Regional Honorary Board of Notaries.

\section{Suggestions}

The authors suggest that confiscation of original deed or the copy of original deed made by the notary have clear and up-to-date laws and regulations. Thus, the notary has stronger guidelines concerning the issue of authentic deeds in the form of original deed that he/she made.

Regarding the issue of time period which is an obstacle for investigators in carrying out the confiscation of original deed, the Regional Honorary Board of Notaries, in the moderate case, should make it clear in 1 (one) month whether a case is included in criminal or civil case and can approve or reject applications submitted at least less than 1 (one) month. Thus, the investigators did not wait too long for confirmation from the Regional Honorary Board of Notaries.

\section{References}

\section{Journals}

Arisaputra, Muhammad Ilham. (2012)."Kewajiban Notaris Dalam Menjaga Kerahasiaan Akta Dalam Kaitannya dengan Hak Ingkar Notaris." Perspektif 17.3: 173-183.

Dinaryanti, Ayu Riskiana. (2013)."Tinjauan Yuridis Legalisasi Akta Di Bawah Tangan Oleh Notaris." Legal Opinion 1.3.

Hendra, Rahmad. (2012). "Tanggungjawab Notaris Terhadap Akta Otentik Yang Penghadapnya Mempergunakan Identitas Palsu di Kota Pekanbaru." Jurnal Ilmu Hukum 3.01.

Santoso, Didi. (2009).Tanggung Jawab Notaris dalam Pembuatan Akta Yang Memuat Dua Perbuatan Hukum (Analisis Putusan Mhkamah Agung Nomor 1440. K/PDT/1996). Diss. program Pascasarjana Universitas Diponegoro. 
Suwignyo, Hadi. (2009). "Keabsahan Cap Jempol sebagai Pengganti Tanda Tangan dalam

Pembuatan Akta Otentik." NOTARIUS 1.1 (2009): 63-74.

Legislation

1945 Constitution of the Republic of Indonesia

Civil Code (Burgerlijk Wetboek)

The Criminal Code

The Criminal Procedure Code, Law number 8 of 1981 dated December 31, 1981.

Law of the Republic of Indonesia number 2 of 2014 concerning Amendment to Law number 30 of 2004 concerning Notary Profession.

Regulation of the Minister of Law and Human Rights number 7 of 2016 concerning the Honorary Board of Notaries.

Regulation of the Minister of Law and Human Rights number M.03.HT.03.10 of 2007 concerning Confiscation of Original Deed and Notary Summon.

Article 66 paragraph (1) letter a of Law number 2 of 2014 and Article 23 paragraph (1) Regulation of the Minister of Law and Human Rights number 7 of 2016.

Interviews

Mr. Eka Kurniawan SH, an investigator of the crime and recession unit in the Bukittinggi Police Station, at the Crime and Recession unit of Bukittinggi Police Station on June 29, 2018, at 1:15 p.m. West Indonesia Time.

Notary Husna Misbah SH, at the Notary Office of Husna Misbah SH, on August 27, 2018, at 2:15 p.m. West Indonesia Time.

Notary Elfita Achtar SH, at the Notary Office of Elfita Achtar SH, on August 27, 2018, at 3:05 p.m. West Indonesia Time.

\section{Copyrights}

Copyright for this article is retained by the author(s), with first publication rights granted to the journal.

This is an open-access article distributed under the terms and conditions of the Creative Commons Attribution license (http://creativecommons.org/licenses/by/4.0/). 